\title{
Nodular non-suppurative panniculitis
}

INSERM

\section{Source}

INSERM. (1999). Orphanet: an online rare disease and orphan drug data base. Nodular non-suppurative panniculitis. ORPHA:33577

A rare skin disorder characterized by recurring inflammation in the subcutaneous layer of fat. 